\title{
Layanan Pesan Pendek untuk Pembangunan Pertanian di Kabupaten Karawang
}

(Short Message Service for Agricultural Development in Karawang District)

\author{
Haris Tri Wibowo ${ }^{1}$, Djuara P Lubis ${ }^{2}$, Resfa Fitri ${ }^{3}$ \\ ${ }^{1}$ Pusat Penyuluhan Pertanian, Kementerian Pertanian \\ ${ }^{2}$ Fakultas Ekologi Manusia IPB, Jl. Kamper Kampus IPB Dramaga \\ ${ }^{3}$ Direktorat Pengelolaan Air Irigasi, Kementerian Pertanian \\ e-mail: hariswibowo2000@yahoo.com
}

\begin{abstract}
Application of information and communication technology (ICTs)currently has integrated with agricultural development. Information and communication technologies (ICTs) such as mobile phones have been used in rural development activities. LISA is a groundbreaking program that aims to provide an integrated agricultural services include agricultural tips services, the interactive dialogue, and iteration financial services based on mobile phone short message service. The main objective of this study to determine the effectiveness of LISA as agricultural information dissemination media based short message service role in agricultural development. The purposes of the study were 1) to analyze the exposure of LISA user; 2) to analyze the relationship between user characteristics and external factors against LISA' exposure; 3) to analyze the relationship between LISA exposure against the effectiveness of communication; and 4) to analyze the relationship between interaction with other information sources against the effectiveness of communication. The sample selection method used in the study was multiple stage sampling. The sample included 100 LISA user in Karawang District. The data analysis was carried out using the descriptive correlational analysis and SEMpls. The result showed that the land area cultivated respondent significantly affect LISA' exposure. External factors do not significantly affect the LISA exposure. LISA exposure significantly affect the effectiveness of communication. Interactions with other information sources does not significantly influence the effectiveness of communication.
\end{abstract}

Keywords: short message service, LISA exposure, the effectiveness of communication

\section{PENDAHULUAN}

Sektor pertanian memiliki peranan penting dalam mendukung perekonomian nasional. Peran tersebut terutama dalam terciptanya ketahanan pangan, penyumbang produk domestik bruto, penciptaan lapangan kerja dan penanggulangan kemiskinan, penyedia bahan pangan dan bahan baku industri, sumber pendapatan masyarakat, serta penciptaan iklim yang kondusif bagi pertumbuhan sektor lainnya (Kementan 2014).

Di sisi lain, sektor ini juga dihadapkan pada tantangan besar untuk selalu berinovasi menghadapi dunia yang global. Untuk menjawab tantangan tersebut, diperlukan sumberdaya manusia pertanian yang andal, berkualitas, dan mempunyai kemampuan. Hal tersebut merupakan hal yang harus dimiliki para pelaku pembangunan pertanian. Pengembangan kualitas pelaku utama dan pelaku usaha pertanian dapat dilakukan melalui pendidikan dan penyuluhan pertanian.

Seiring dengan perkembangan teknologi, aplikasi teknologi informasi dan komunikasi (TIK) sudah terintegrasikan dalam berbagai kegiatan pembangunan dan pengembangan masyarakat. Teknologi informasi dan komunikasi, seperti telepon seluler, telepon fixed-line, komputer, dan internet, telah menjadi bagian integral dari kehidupan modern dalam semua masyarakat. 
Telepon seluler memiliki kelebihan dibandingkan dengan teknologi informasi komunikasi lainnya, antara lain mudah dan fleksibel dalam penggunaannya. Dengan kelebihan tersebut, PT 8villages Indonesia dengan didukung Agri-Fin Mobile dari Mercy Corp Indonesia meluncurkan layanan diseminasi informasi pertanian berbasis telepon seluler melalui Layanan Informasi Desa (LISA). LISA merupakan sebuah program yang bertujuan memberikan layanan pertanian terintegrasi melalui telepon seluler meliputi tips-tips pertanian, tanya jawab masalah pertanian, dan informasi pasar. Petani pengguna dari berbagai daerah terhubung dengan pusat layanan melalui LISA.

Fenomena pemakaian TIK sebagai sarana diseminasi informasi pertanian masih merupakan fenomena yang tergolong baru di Indonesia. Penelitian mengenai cyber extension yang berbasis layanan internet, diketahui bahwa cyber extension dimanfaatkan sebagai sarana komunikasi dan berbagi informasi, serta untuk akses informasi mengenai usahatani. Penelitian Mulyandari (2011), menyatakan bahwa sebagian petani di Jawa Barat dan Jawa Timur dalam kegiatannya sehari-hari, tidak pernah lepas dari penggunaan terutama telepon seluler. Telepon seluler digunakan untuk mencari informasi mengenai harga pasar komoditas yang diusahakan, transaksi secara elektronis, serta mendongkrak jangkauan pemasaran produknya.

Sejalan dengan uraian di atas, untuk mengetahui sejauh mana efektivitas LISA sebagai media diseminasi informasi pertanian yang berbasis layanan pesan pendek berperan dalam pembangunan pertanian, perlu dilakukan kajian dan analisis secara mendalam dan terarah.
Tujuan utama penelitian ini adalah untuk mengetahui sejauh mana efektivitas LISA sebagai media diseminasi informasi pertanian yang berbasis layanan pesan pendek berperan dalam pembangunan pertanian. Sedangkan tujuan khusus penelitian ini antara lain: 1) Mendeskripsikan keterdedahan pengguna terhadap LISA; 2) Menganalisis hubungan karakteristik petani dan faktor eksternal dengan keterdedahan terhadap LISA; 3) Menganalisis hubungan keterdedahan terhadap LISA dengan efektivitas komunikasi LISA; dan 4). Menganalisis hubungan interaksi dengan sumber informasi lain dengan efektivitas komunikasi LISA.

\section{TINJAUAN PUSTAKA}

Teknologi informasi dan komunikasi (TIK) didefinisikan sebagai seperangkat alat yang kompleks dan heterogen, aplikasi dan layanan yang digunakan untuk memproduksi, mendistribusikan, pengolahan dan pengiriman informasi (Marcelle 2000 dalam Kituyi dan Adigun 2008; Afolabi 2012 dalam Zahedi dan Zahedi 2012) menggunakan mikro elektronika, optik, telekomunikasi, dan komputer (FAO 1993 dalam Olaniyi et al. 2013). Zahedi dan Zahedi (2012) mendefinisikan TIK sebagai teknologi yang dapat membantu pertukaran informasi dengan cara yang cepat dan mudah, yang menghilangkan jarak atau perbedaan geografis antara bangsabangsa dan menjadikan dunia menjadi sebuah desa global (Zahedi dan Zahedi 2012). Technical Centre for Agricultural and Rural Cooperation (CTA, 2003) dalam Olaniyi et al. (2013) mendefinisikan TIK sebagai teknologi yang mempermudah komunikasi dan proses pengiriman informasi melalui sarana elektronik untuk kepentingan penggunanya. 
Ngenge (2003) dalam Kituyi dan Adigun (2008) menganggapnya sebagai teknologi yang memungkinkan penanganan informasi dan memfasilitasi berbagai bentuk komunikasi antara manusia, manusia dan sistem elektronik, dan antara sistem elektronik.

TIK merupakan salah satu terobosan yang mendorong pengembangan dan perubahan sekarang ini. Transformasi besar dalam kehidupan orang-orang terutama di negara-negara berkembang tergantung pada kemajuan TIK (Emenari 2004 dalam Olaniyi et al. 2013). Pesatnya perkembangan TIK memiliki pengaruh besar terhadap penghidupan orang di seluruh dunia. Penerapan TIK dapat menjadi pendorong utama pembangunan ekonomi dan masyarakat di daerah pedesaan (Osiakade et al. 2010 dalam Olaniyi et al. 2013). Perkembangan TIK telah meruntuhkan batas nasional dan internasional dan mengubah dunia menjadi sebuah desa global, membuat informasi tersedia untuk semua orang, di mana-mana dan kapan saja diperlukan (Onasanya et al. 2011 dalam Olaniyi et al. 2013). TIK mempunyai peranan penting dalam menghadapi berbagai tantangan dan mengangkat penghidupan di pedesaan (ITU 2009 dalam Olaniyi et al. 2013). Penggunaan radio, televisi dan telepon seluler untuk menyebarkan informasi pertanian yang sesuai kepada petani dapat mendorong pencapaian ketahanan pangan dan mendukung kehidupan pedesaan di Nigeria (Olaniyi et al. 2013). Peran TIK dalam penyuluhan dapat mendorong terjadinya realisasi bottom-up, mendorong masuk ke generasi tehnologi (Meera 2003 dalam Moon 2013). Penggunaan telepon seluler dapat meningkatkan keuntungan dan kesejahteraan nelayan India (Jensen
2007 dalam Kilenthong dan Odton 2014); mengurangi biaya yang dikeluarkan dalam berusahatani (Ogutu et al. 2014).

Meskipun disadari TIK memiliki peranan yang sangat penting dalam mendukung pembangunan pertanian berkelanjutan, namun sampai saat ini petani di dunia, khususnya di Indonesia masih belum dipertimbangkan dalam bisnis TIK dan lingkungan kebijakan (Lubis 2010).

Krysa (1998) dalam Moghaddam dan Abadi (2013) menjadikan keterampilan dalam penggunaan instrumen TIK termasuk komputer sebagai faktor penghambat dalam adopsi TIK. Penerapan TIK tergantung pada keterampilan pengguna komputer. Taragola et al. (2009) dalam Lubis (2010) mengindikasikan beberapa hambatan yang dihadapi petani hortikultura dalam mengadopsi TIK, yaitu: keterbatasan kemampuan, kesenjangan dalam pelatihan (training), kesadaran akan manfaat TIK, waktu, biaya dari teknologi yang digunakan, integrasi sistem dan ketersediaan software.

Pemanfaatan TIK dalam pembangunan pertanian berkelanjutan membutuhkan proses pendidikan dan peningkatan kapasitas karena masih terdapat kesenjangan secara teknis maupun keterampilan dalam bisnis secara elektronik (Lubis 2010). Senada dengan Lubis (2010), Moghaddam dan Abadi (2013) merekomendasikan bahwa sebelum membuat program pemberdayaan berbasis TIK, maka harus ada program pelatihan yang dapat mendukung peningkatan ketrampilan penggunaan TIK. Pelatihan TIK dapat memberikan dorongan baru untuk kegiatan pertanian, yang dapat bertindak sebagai agen transformatif untuk pengembangan pedesaan (Botsiou dan Dagdilelis 2013). Dalam sebuah 
ISSN 1693-3699 (Cetak)

ISSN 2442-4102

program berbasis TIK di Malaysia, sebagian besar peserta pelatihan TIK mempunyai lebih banyak pengetahuan dan keterampilan tentang penggunaan komputer dan akses internet (Hashima et al. 2011).

\section{Kerangka Pemikiran}

Penelitian ini menggunakan lima peubah. Tiga peubah bebas, yaitu: 1) karakteristik responden (dengan indikator: umur, pendidikan, kepemilikan lahan, luas lahan, dan pekerjaan utama); 2) faktor eksternal (dengan indikator: layanan LISA dan layanan operator seluler); dan 3) interaksi dengan sumber informasi lain (terdiri dari tiga indikator: interaksi dengan pemuka pendapat, interaksi dengan kelompoktani, dan interaksi dengan penyuluh pertanian). Peubah terikat dalam penelitian ini adalah keterdedahan terhadap LISA (dengan indikator frekuensi akses dan kesesuaian konten) dan efektivitas komunikasi (dengan indikator tingkat pengetahuan dan sikap).

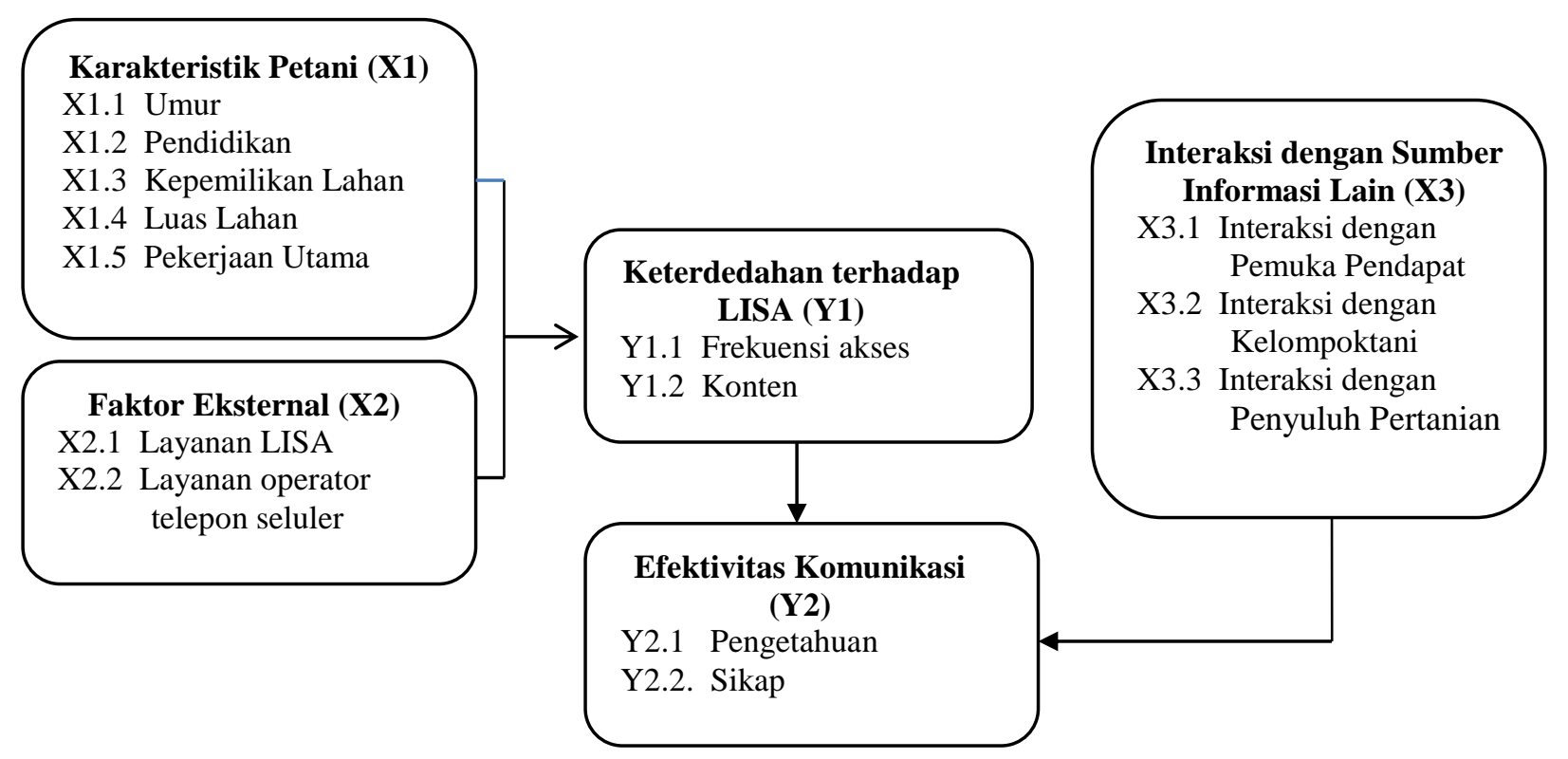

Gambar 1 Kerangka pemikiran layanan pesan pendek untuk pembangunan pertanian di Kabupaten Karawang

\section{METODOLOGI}

Penelitian ini merupakan penelitian survei yang bersifat deskriptif korelasional. Lokasi penelitian dipilih secara sengaja, yaitu di Kabupaten Karawang, Jawa Barat. Waktu pelaksanaan penelitian dilakukan pada bulan Mei 2015 sampai dengan Juni 2015. Teknik penarikan sampel yang digunakan dalam penelitian adalah Multiple Stage Sampling. Teknik ini dilakukan dua tahap yang terdiri dari pemilihan kecamatan untuk menjadi subpopulasi dan pemilihan responden di setiap kecamatan terpilih. Pertama, pemilihan kecamatan yang dijadikan subpopulasi dan terpilih empat kecamatan, yaitu Kecamatan Pangkalan, Kecamatan Jatisari, Kecamatan Karawang Timur, dan Kecamatan Pedes. Kedua, pemilihan responden dilakukan secara accidental sampling atau disebut juga convenience sampling. Jumlah responden yang diambil sebagai sampel ditentukan dengan menggunakan 
ISSN 1693-3699 (Cetak)

ISSN 2442-4102

rumus Slovin sebanyak 92 orang. Dalam pelaksanaannya, jumlah responden menjadi 100 orang responden. Data yang dikumpulkan dalam penelitian ini dianalisis dengan analisis deskriptif dan analisis model persamaan struktural dengan Partial Least Square menggunakan SmartPLS.

\section{DESKRIPSI UMUM}

Deksripsi Lokasi Penelitian

Kabupaten Karawang mempunyai wilayah 1.1753, $27 \mathrm{~km}^{2}$ atau sebesar 3,73 persen luas Propinsi Jawa Barat. Kabupaten Karawang terdiri dari 30 kecamatan dengan jumlah desa sebanyak 297 desa dan 12 kelurahan (BPS Karawang 2014). Lokasi

penelitian berada di empat kecamatan, yaitu Kecamatan Pangkalan, Kecamatan Jatisari, Kecamatan Karawang Timur, dan Kecamatan Pedes.

\section{Karakteristik Responden}

Karakteristik responden dianggap sebagai salah satu unsur penting yang menentukan tingkat keterdedahan serta efektivitas komunikasi sebagai sasaran akhir. Karakteristik ini dijelaskan dengan peubah umur, pendidikan terakhir, status kepemilikan lahan, luas lahan, dan pekerjaan utama.

Tabel 1 Jumlah responden menurut karakteristik di 4 kecamatan lokasi penelitian tahun 2015

\begin{tabular}{llrr}
\hline \multicolumn{1}{c}{ Karakteristik Responden } & $\begin{array}{r}\text { Jumlah } \\
\text { (orang) }\end{array}$ & $\begin{array}{r}\text { Persen } \\
(\%)\end{array}$ \\
\hline Umur & $<20$ tahun & 1 & 1.00 \\
& $20-29$ tahun & 9 & 9.00 \\
& $30-59$ tahun & 88 & 88.00 \\
& $\geq 60$ tahun & 2 & 2.00 \\
Pendidikan & SD atau sederajat & 49 & 49.00 \\
& SMP atau sederajat & 27 & 27.00 \\
& SMA atau sederajat & 17 & 17.00 \\
& Diploma & 2 & 2.00 \\
Status kepemilikan lahan & Sarjana & 5 & 5.00 \\
& milik sendiri & 43 & 57.00 \\
Luas lahan & Sewa/gadai /buruh/penggarap & 51 & 51.00 \\
& Sempit $\left(<8.800 \mathrm{~m}^{2}\right)$ & 34 & 34.00 \\
Pekerjaan & Sedang $\left(8.800-19.200 \mathrm{~m}^{2}\right)$ & 15 & 15.00 \\
& Luas $\left(>19.200 \mathrm{~m}^{2}\right)$ & 81 & 81.00 \\
& Petani & 19 & 19.00 \\
\hline
\end{tabular}

\section{Layanan LISA}

LISA diperkenalkan kepada masyarakat di Kabupaten Karawang pada Desember 2012 bersamaan dengan peresmian layanan yang dilakukan di Kecamatan Jatisari dan Kecamatan Cilamaya. Saat ini diperkirakan sekitar 3.800 masyarakat yang menjadi pengguna LISA di Kabupaten Karawang, Kabupaten Subang, Kabupaten Indramayu, dan 
ISSN 1693-3699 (Cetak)

ISSN 2442-4102

Kabupaten Bogor. Ada juga pengguna yang berasal dari luar 4 kabupaten tersebut. Jumlah pengguna LISA di Kabupaten Karawang di perkirakan sebanyak 1.200 orang.

Layanan LISA mencakup layanan tips pertanian, layanan tanya jawab interaktif, dan layanan iterasi keuangan keluarga. Pemilihan materi didasarkan atas tematik dari operator LISA yang merujuk pada program pemerintah, berasal dari tren yang sedang berkembang di masyarakat, atau tematema yang menjadi perhatian pengguna dalam layanan tanya jawab interaktif.

Masyarakat dapat menjadi pengguna layanan LISA pada Agri-Fin Mobile dengan mendaftarkan diri melalui telepon seluler dengan cara ketik "LISA (spasi) IKUTI (spasi) NOMOR TELEPON" dan dikirim ke 2000. Setelah terdaftar sebagai pengguna LISA, maka pengguna dapat menggunakan beberapa layanan yang disediakan, seperti tips pertanian dan layanan tanya jawab interaktif dengan ahli pertanian. Prosedur untuk menggunakan layanan tanya jawab interaktif, dilakukan dengan mengetik "LISA (spasi) TANYA (spasi) PERTANYAAN" kemudian kirim ke nomor 2000.

Dalam menjalankan layanan LISA, operator LISA juga bekerjasama dengan Institut Pertanian Bogor (IPB) untuk menjadi sumber informasi pertanian. Tenaga-tenaga ahli dari IPB memberikan informasi pertanian, inovasi pertanian, dan juga menjawab pertanyaan-pertanyaan dari pengguna melalui LISA. Selain dari perguruan tinggi, operator LISA juga menggandeng penyuluh pertanian lokal untuk menjadi narasumber dalam layanan. Saat ini layanan tips pertanian dibagikan kepada penggunanya dua kali dalam satu minggu. Oleh karena terbatasnya karakter dalam layanan pesan pendek, operator LISA membagikan satu tema tips pertanian dengan cara mengirimkan pesan pendek sebanyak dua kali.

Dalam penelitian ini, variabel bebas yang dapat mempengaruhi keterdedahan terhadap LISA adalah layanan LISA. Layanan LISA merupakan variabel bebas untuk mengukur kepuasan responden terhadap kualitas layanan yang diberikan operator LISA. Berikut merupakan salah satu contoh tips pertanian dan tanya jawab interaktif dalam LISA:

\begin{tabular}{l}
$\frac{\text { Tips pertanian }}{\text { Tanaman yang tiba-tiba layu di antaranya dapat }}$ \\
disebabkan oleh kekeringan, adanya serangan \\
hama atau penyakit, kelebihan pupuk, perakaran \\
tercabut, (1/2) \\
perakaran tanaman tercabut, maupun suhu \\
lingkungan yang panas sehingga terjadi \\
penguapan air yang berlebihan dari tanaman \\
[Guntoro-IPB] (2/2) \\
\hline Layanan tanya jawab \\
Pertanyaan: Pada penanaman padi organik, \\
kapan sebaiknya pemberian MOL dilakukan? \\
\hline MOL dapat diberikan pada saat sebelum tanam \\
(saat pengolahan lahan), kemudian dilanjutkan \\
setelah tanam setiap 10 hari sekali [Ramdhani- \\
BP3K Pedes]
\end{tabular}

Hasil penelitian menunjukkan bahwa sebanyak 97 responden menyatakan puas terhadap pelayanan yang diberikan oleh LISA. Hanya 3 persen responden yang menyatakan kurang puas atas layanan yang diberikan LISA.

Ditinjau dari aspek bahasa, sebagian besar responden menyatakan bahwa bahasa yang digunakan dalam LISA mudah dipahami (81 persen), 15 responden menyatakan sangat mudah dipahami. Hanya 4 persen responden yang menyatakan bahwa bahasa yang digunakan dalam LISA kurang mudah dipahami.

Tips/ jawaban/ ulasan yang diberikan kepada pengguna dianggap lengkap dan rinci oleh sebagian besar 
pengguna. Sebanyak 74 persen pengguna menyatakan bahwa tips/ jawaban/ ulasan yang diberikan memuat hal yang rinci dan lengkap, 16 persen penggguna menyatakan sangat rinci dan lengkap, dan 10 persen sisanya menganggap tips/ jawaban/ ulasan kurang rinci dan masih memerlukan penjelasan lebih lanjut.

Selain itu, sebagian besar responden menyatakan bahwa tips/ jawaban/ ulasan yang diberikan LISA dapat diterapkan, dan hanya dua persen responden menyatakan kurang dapat diterapkan dalam praktek di lapangan.

\section{KETERDEDAHAN TERHADAP LISA}

\section{Keterdedahan terhadap LISA}

Keterdedahan terhadap LISA berhubungan dengan frekuensi pengguna terdedah terhadap LISA dan kesesuaian konten/materi yang diterima pengguna dapat memenuhi kebutuhan dan kepuasan. Pada awal peluncuran layanan LISA sampai pada bulan Mei 2015, setiap pengguna layanan LISA mendapat tips pertanian setiap hari. Layanan tips pertanian ini kemudian mengubah frekuensi pengiriman tips pertanian menjadi dua kali dalam satu minggu. Perubahan frekuensi ini disebabkan berakhirnya pembiayaan dari Agri-Fin Mobile.

Gambar 2 menunjukkan bahwa akses pengguna ke layanan tips pertanian tergolong tinggi. Hasil sebaliknya ditunjukkan oleh pengguna dalam mengakses layanan tanya jawab interaktif. Frekuensi pengguna mengakses layanan tanya jawab interaktif tergolong rendah.

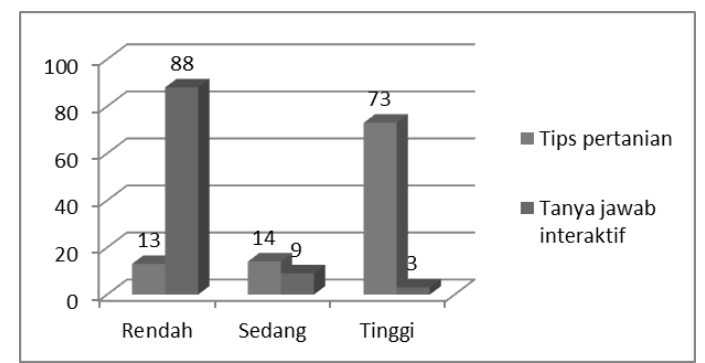

Gambar 2 Frekuensi akses responden terhadap layanan LISA

\section{Kesesuaian Konten}

Kekesuaian konten adalah kesesuaian konten/materi yang diperoleh responden dari layanan LISA dengan kebutuhan reponden terhadap informasi pertanian. Kesesuaian konten diukur berdasarkan penilaian responden terhadap kesesuaian materi dalam layanan LISA dengan kebutuhan responden, baik materi dalam tips pertanian maupun layanan tanya jawab interaktif.

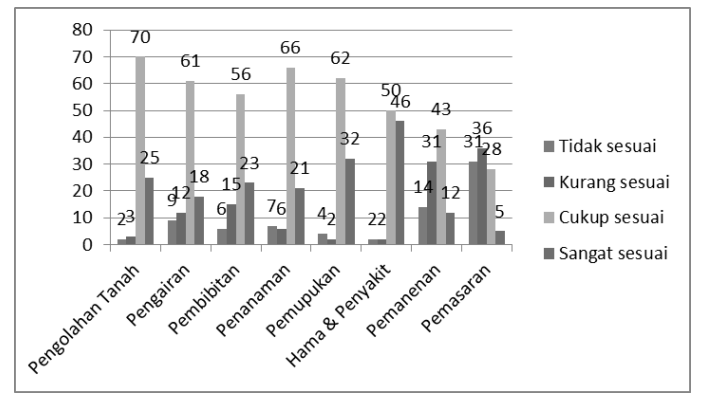

Gambar 3 Penilaian responden
terhadap konten LISA

Gambar 3 menunjukkan bahwa sebagian besar responden menyatakan konten layanan LISA sesuai dengan kebutuhan responden, dalam materi pengolahan tanah, pengairan, pembibitan, penanaman, pemupukan, pengendalian hama dan penyakit, dan pemanenan. Penggunaan bahasa yang sederhana, konten-konten lokal, dan pemilihan tema berdasarkan analisis kebutuhan pengguna menunjukkan bahwa sebagian besar pengguna menyetujui dan menerima kontenkonten yang disediakan. Konten lokal yang sesuai dengan kebutuhan akan 
ISSN 1693-3699 (Cetak)

ISSN 2442-4102

menjadi materi yang menarik bagi pengguna layanan. Pemilihan konten lokal merupakan salah satu prinsip untuk keberhasilan penerapan teknologi informasi dan komunikasi untuk masyarakat desa (Flor 2008 dalam Lubis 2012).

Mayoritas menyatakan kurang sesuai dan tidak sesuai terhadap konten pemasaran. Hal ini disebabkan oleh beberapa faktor, antara lain kurangnya konten mengenai pemasaran, ulasan mengenai pemasaran kurang lengkap, dan lamanya respon terhadap pertanyaan mengenai pemasaran. Narula dan Arora (2010) menyatakan bahwa salah pendorong penggunaan TIK oleh petani adalah memanfaatkan layanan di bidang pertanian, terutama yang berhubungan dengan pasar dan konsumen.

\section{Hubungan Karakteristik Responden dengan Keterdedahan LISA}

Jurnal Komunikasi Pembangunan Juli 2015. Vol.13, No.2

Analisis

menggunakan smartPLS didapatkan hasil peubah umur, pendidikan, status kepemilikan lahan, pekerjaan, dan layanan operatr telepon seluler memiliki nilai outer faktor kurang dari 5\%, sehingga untuk kebaikan model peubah-peubah tersebut dihilangkan dan dilakukan perhitungan ulang. Gambar 4 merupakan model perbaikan setelah beberapa peubah dihilangkan.

Model persamaan struktural pada Gambar 4 menunjukkan bahwa semua outer loading sudah melebihi nilai 0.5 . Hal ini berarti indikator dikatakan valid dan realibel mengukur variabel latennya. Selanjutnya dilakukan evaluasi pengukuran model untuk mengetahui model yang dibentuk sudah baik atau belum menggunakan uji cross loading. Hasil evaluasi menunjukkan bahwa masing-masing indikator sesuai untuk menggambarkan/ mewakili konstruknya.

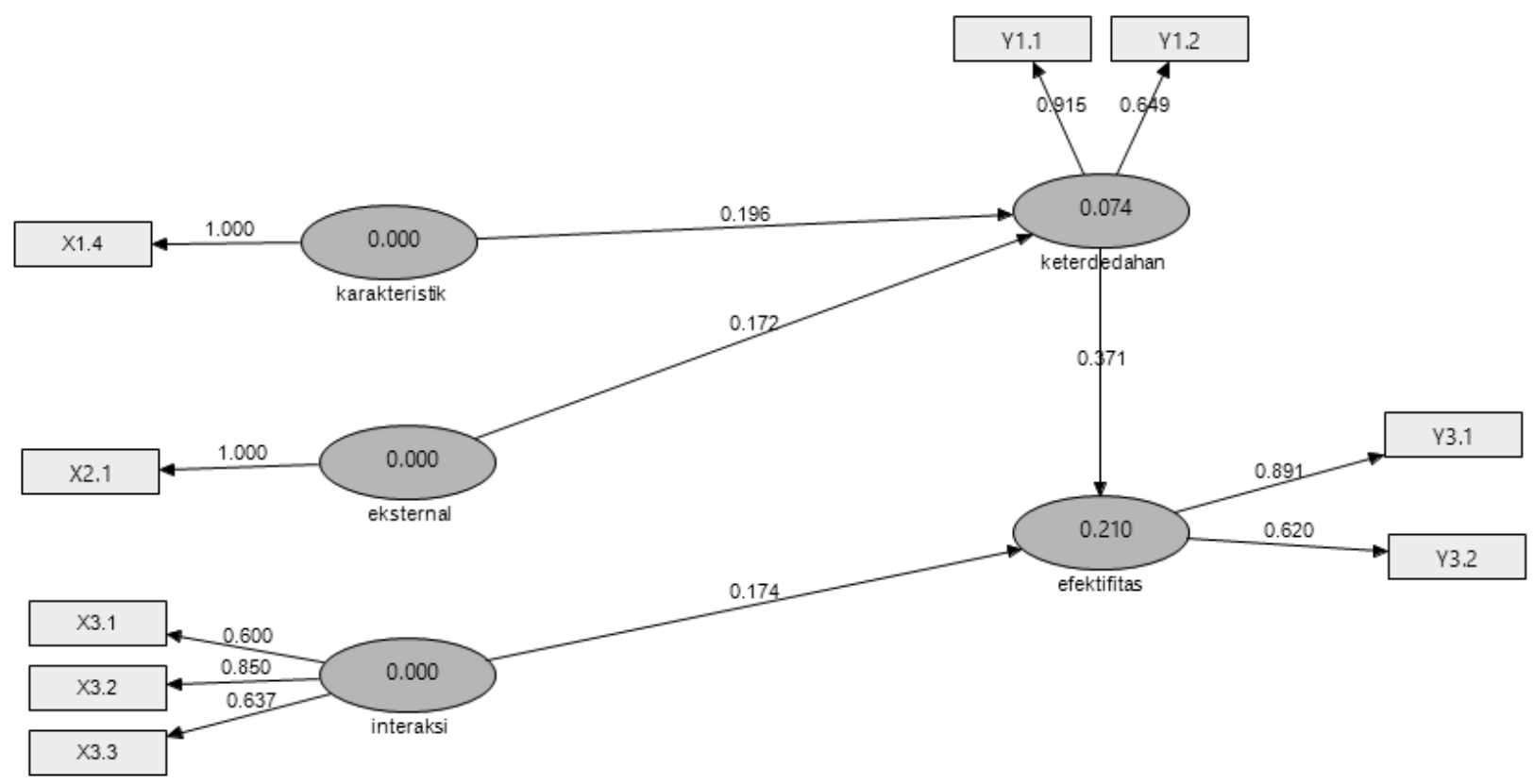

Keterangan:

X1.4 = luas lahan, X2.1 = layanan LISA, X3.1 = interaksi dengan pemuka pendapat, X3.2 = interaksi dengan kelompoktani, X3.3 = interaksi dengan penyuluh pertanian, Y1.1 = frekuensi akses, Y1.2 = kesesuaian konten, Y2.1 = tingkat pengetahuan, Y2.2 = sikap

Gambar 4 Model perbaikan layanan pesan pendek untuk pembangunan pertanian di Kabupaten Karawang 
Untuk melihat pengaruh konstruk terhadap konstruk lainnya dilakukan uji koefisien. Pada Tabel 2, koefisien karakteristik pengguna terhadap keterdedahan sebesar 0,196 dan mempunyai nilai $\mathrm{t}$ statistik sebesar 2,105. Hal ini berarti bahwa $\mathrm{H}_{0}$ ditolak atau $\mathrm{H}_{1}$ diterima. Karakteristik berpengaruh signifikan pada tingkat keterdedahan mereka. Semakin tinggi nilai karakteristik pengguna layanan LISA maka akan semakin tinggi pula tingkat keterdedahan pengguna tersebut.

Tabel 2 Uji koefisiensi dan t hitung variabel karakteristik, faktor ekternal terhadap keterdedahan LISA dan efektivitas komunikasi

\begin{tabular}{lcccc}
\hline & koefisien & $\mathrm{T}_{\text {- } \text { hitung }}$ & $\begin{array}{c}\mathrm{T}_{\text {-tabel }} \\
(\alpha 5 \%)\end{array}$ & Keterangan \\
\hline $\begin{array}{l}\text { Karakteristik } \\
\text { terhadap }\end{array}$ & 0.196139 & 2.105025 & & Signifikan \\
$\begin{array}{l}\text { Keterdedahan } \\
\text { eksternal terhadap } \\
\text { keterdedahan }\end{array}$ & 0.172143 & 1.634179 & 1,96 & Tidak signifikan \\
$\begin{array}{l}\text { Keterdedahan } \\
\text { terhadap } \\
\text { efektifitas }\end{array}$ & 0.371483 & 3.604901 & & Signifikan \\
$\begin{array}{l}\text { Interaksi terhadap } \\
\text { efektifitas }\end{array}$ & 0.174472 & 1.693176 & & Tidak signifikan \\
\hline
\end{tabular}

\section{Hubungan Faktor Eksternal dengan Keterdedahan LISA}

Hasil uji koefisien faktor eksternal terhadap keterdedahan LISA sebesar 0,172 dan mempunyai nilai $\mathrm{t}$ statistik sebesar 1,634 ( $\mathrm{t}_{\text {-tabel }} 0,05$ sebesar 1,96$)$. Hal ini berarti bahwa $\mathrm{H}_{0}$ diterima. Artinya tidak cukup bukti bahwa faktor eksternal berpengaruh signifikan pada tingkat keterdedahan mereka.

\section{EFEKTIVITAS KOMUNIKASI}

Komunikasi melalui layanan pesan singkat dikatakan efektif apabila terjadi perubahan pengetahuan dan sikap pada penerima pesan. Efektivitas komunikasi merujuk kepada perubahan yang terjadi dalam diri responden setelah menerima informasi dari layanan LISA. Perubahan yang diukur pada dua indikator perilaku mencakup peningkatan kesadaran dan perubahan pengetahuan (kognitif) dan efek yang berhubungan dengan emosi, perasaan dan sikap (afektif).

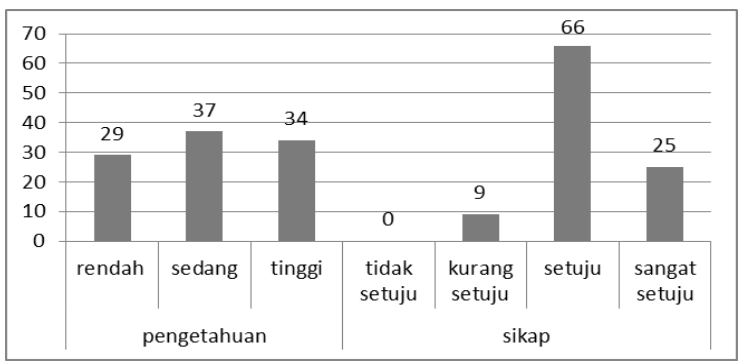

Gambar 5 Tingkat pengetahuan dan sikap responden terhadap konten LISA 

Tingkat pengetahuan responden diukur berdasarkan pemahaman responden terhadap konten yang berasal dari LISA. Sikap responden diukur dari kecenderungan sikap responden terhadap konten LISA dan kemauan melakukan kegiatan sesuai konten.

\section{Hubungan Keterdedahan terhadap LISA dengan Efektivitas Komunikasi}

Hasil pengujian koefisiensi keterdedahan LISA terhadap efektivitas komunikasi sebesar 0.371 dan mempunyai perhitungan $\mathrm{t}$ sebesar 3,605 (Tabel 2). Nilai t hitung tersebut lebih besar dari t-tabel 1,96 pada $\alpha 0,05$ yang berarti bahwa keterdedahan terhadap LISA mempunyai pengaruh signifikan kepada efektivitas komunikasi. Semakin tinggi nilai keterdedahan terhadap LISA akan meningkatkan efektivitas komunikasi LISA.

Hasil penelitian menunjukkan bahwa layanan pesan pendek dapat digunakan untuk kegiatan penyuluhan. Hal ini sejalan dengan temuan Oraegbunam (2009) yang meneliti efektivitas komunikasi media internet untuk melakukan kegiatan konseling. Prajanti et al. (2013) menyatakan bahwa teknologi informasi dan komunikasi terbukti mempermudah dan mendukung kegiatan penyuluhan oleh penyuluh pertanian. Komunikasi massa melalui telepon seluler efektif untuk mempengaruhi pengetahuan dan sikap penerima. Layanan pesan pendek terbukti mampu untuk meningkatkan pengetahuan penerima dan mengarahkan kecenderungan sikap penerima untuk mengikuti apa yang disampaikan LISA. Layanan pesan pendek terbukti berperan dalam diseminasi informasi pertanian. Prihandoyo (2014) menyatakan bahwa telah terpjadi perubahan proses diseminasi informasi di kalangan petani dari cara konvensional menjadi modern dengan memanfaatkan teknologi informasi komunikasi yang melibatkan teknologi komputer dan internetnya serta telepon seluler.

\section{Hubungan Interaksi dengan Sumber Informasi lain dengan Efektivitas Komunikasi}

Hasil pengujian koefisiensi interaksi dengan sumber informasi lain terhadap efektivitas komunikasi sebesar 0.174 dan mempunyai perhitungan $t$ sebesar 1,693 (Tabel 2). Nilai t hitung tersebut kurang dari t-tabel 1,96 pada $\alpha 0,05$ yang berarti bahwa belum cukup bukti interaksi dengan sumber informasi lain berpengaruh signifikan terhadap efektivitas komunikasi.

Hasil penelitian menunjukkan bahwa komunikasi massa melalui telepon seluler terbukti efektif untuk diseminasi informasi. Akan tetapi tidak mungkin komunikasi massa akan efektif berjalan sendiri untuk mengubah pengetahuan dan menggerakkan sikap pengguna tanpa di barengi dengan komunikasi interpersonal. Tabel 2 menunjukkan bahwa pengaruh interaksi responden dengan sumber informasi lain terhadap efektivitas komunikasi sebesar 1,693. Artinya selain komunikasi massa melalui telelpon seluler, pengetahuan dan sikap responden dipengaruhi oleh interaksi tatap muka dengan pemuka pendapat, kelompoktani, dan penyuluh pertanian. Schramm (1984) menyatakan bahwa tidak ada media komunikasi yang efektif untuk memenuhi semua keperluan. Suatu kombinasi media komunikasi akan lebih efektif untuk mencapai tujuan komunikasi. Komunikasi interpersonal merupakan 
ISSN 1693-3699 (Cetak)

ISSN 2442-4102

unsur yang tidak dapat dilepaskan dalam penggunaan komunikasi massa. Lowery dan De Fleur (1983) komunikasi interpersonal mempunyai pengaruh yang besar dalam mempengaruhi opini khalayak. Komunikasi interpersonal dapat menimbulkan efek perubahan perilaku. Komunikasi massa dapat menyampaikan informasi dalam jumlah banyak dan dalam waktu yang singkat serta memberikan efek kognitif yang meliputi peningkatan kesadaran untuk belajar dan menambah pengetahuan. Media massa memiliki peranan memberikan informasi untuk memperluas cakrawala, memusatkan perhatian, menumbuhkan aspirasi dan sebagainya (Soekartawi 1988).

\section{SIMPULAN DAN SARAN}

\section{Simpulan}

1. Tingkat keterdedahan responden terhadap tips pertanian tergolong tinggi sedangkan tingkat partisipasi responden dalam layanan tanya jawab interaktif tergolong rendah;

2. Luas lahan merupakan karakteristik responden yang paling berpengaruh terhadap keterdedahan LISA;

3. Keterdedahan responden terhadap LISA berpengaruh signifikan terhadap efektivitas komunikasi. Layanan LISA yang berbasis layanan pesan pendek dapat digunakan untuk media penyuluhan pertanian;

4. Komunikasi personal antara responden dengan pemuka pendapat, kelompoktani, dan penyuluh pertanian merupakan hal yang diperlukan untuk mendukung komunikasi melalui pesan pendek.

\section{Saran}

1. Hal yang perlu diperhatikan untuk meningkatkan kualitas layanan informasi pertanian yang berbasis
Jurnal Komunikasi Pembangunan Juli 2015. Vol.13, No.2

layanan telepon seluler, antara lain memperbanyak konten bertema pemasaran produk pertanian, memperbanyak konten yang dapat mendorong keterlibatan perempuan dalam layanan, menambah frekuensi layanan tip pertanian, dan membuat terobosan inovatif;

2. Peran penyuluh pertanian perlu ditingkatkan untuk pengembangan layanan LISA.

\section{DAFTAR PUTAKA}

Botsiou M, Dagdilelis V. 2013. Aspects of incorporation of ict in The Greek agricultural enterprises: the case of a prefecture. Procedia Technology .8:387- 396

Hashima F, Amir Z, Razak NA. 2011. Empowering rural women entrepreneurs with ict skills: an impact study. Procedia Social and Behavioral Sciences. 15:3369-3373

Kilenthong WT, Odton P. 2014. Access to ict in rural and urban Thailand. Telecommunications Policy 38:1146-1159

Kituyi KA, Adigun .2008. Analyzing ICT use and access amongst rural women in Kenya. Internat $\mathbf{J}$ of Educ and Developm using Informat and Comm Tech (IJEDICT). 4 (4) :127147

Lowery S, De Fleur ML. 1983. Milestones in Mass Communication Research: Media Effect. New York: Longman Inc

Lubis DP. 2012. Agricultural extension in Indonesia: current status and possible ways to meeting emerging challenges [diunduh pada 4 April 2015]. Tersedia pada http://www. syngentafoundation.org/ temp/lubi s_indonesia_agricultural_extension. pdf 
ISSN 1693-3699 (Cetak)

ISSN 2442-4102

Moghaddam BK, Abadi AK. 2013. Factors affecting ict adoption among rural users : a case study of ict center in Iran. Telecommunications Policy. 37:1083-1094

Moon SJ. 2013. "Awareness of The Farmers about Benefit of Using Information and Communication Technology (ICT) towards Increased Farm Productivity in Bangladesh". [Tesis]. Norwegia (NO) : Norwegian University of Life Sciences

Mulyandari RSH. 2011. Cyber Extension sebagai Media Komunikasi dalam Pemberdayaan Petani Sayuran [disertasi]. Bogor (ID): Institut Pertanian Bogor

Narula SA, Arora S. 2010. Identifying stakeholders' needs and constraints in adoption of ICTservices in rural areas:the case of India. Social Responbility Journal. 6:222-236

Ogutu SO, Okello JJ, Otieno DJ. 2014. Impact of information and communication technology-based market information services on smallholder farm input use and productivity: the case of Kenya. World Dev. 64:311-321

Olaniyi OA, Adetumbi SI, Adereti MA. 2013. Accessibility and relevance of information and communication technologies (icts) among cassava farmers in Nigeria. African Journal of Agricultural Research. $8(35): 4514-4522$

Oraegbunam NM. 2009. Applying information and communication technology in counseling practice. Procedia Social and Behavioral Sciences. 1:1749-1752

Prajanti SDW, Djuniadi, Soesilowati E. 2013. Evaluation on benefits and development of information and communication technology (ICT) to improve the performance of
Jurnal Komunikasi Pembangunan

Juli 2015. Vol.13, No.2

agricultural extension in Central Java. International Journal of Organizational Innovation. October 6(2):243-253

Prihandoyo WB. 2014. "Efektivitas Diseminasi Informasi Pertanian melalui Media Telepon Genggam pada Petani Sayuran di Kecamatan Pacet, Kabupaten Cianjur". [tesis]. Bogor (ID): Institut Pertanian Bogor

Schramm W. 1984. Media Besar Media Kecil: Alat dan Teknologi untuk Pendidikan. Semarang: IKIP Semarang Press

Soekartawi. 1988. Prinsip Dasar Komunikasi Pertanian. Jakarta (ID): UI Press

Zahedi SR, Zahedi SM. 2012. Role of information and communication technologies in modern agriculture. International Journal of Agriculture and Crop Sciences. 4(23):1725-1728 
ISSN 1693-3699 (Cetak)

Jurnal Komunikasi Pembangunan

ISSN 2442-4102

Juli 2015. Vol.13, No.2 